\title{
Pelatihan Aplikasi Sarana Pemasaran Online Imooji Untuk Mitra Produk Gusereen di Masa Pandemi Covid-19
}

\section{(Training on Online Marketing Tool Application of Imooji for Gusereen Product During the Covid-19 Pandemic)}

\author{
Latifa Hanum*, Regia Indah Kemala Sari, Riva Hendriani, Siska Fitrianti \\ Program Studi Agribisnis, Politeknik Pertanian Negeri Payakumbuh, Jl Raya Negara Km 7 Tanjung Pati, \\ Kabupaten Limapuluh Kota, Sumatera Barat 26271. \\ *Penulis korespondensi: justhanum@gmail.com \\ Diterima Desember 2020/Disetujui September 2021
}

\begin{abstract}
ABSTRAK
Pemasaran produk gula semut aren di Kabupaten Lima Puluh Kota masih dikelola secara tradisional, belum memanfaatkan pemasaran online. Pemasaran produk Gusereen masih mengandalkan words of mouth dan penggunaan grup di media sosial yang terbatas. Kegiatan pelatihan ini bertujuan untuk memberikan pengetahuan tentang cara pembuatan brosur digital imooji bagi produk Gusereen sebagai sarana promosi dan penjualan produk mitra. Pengumpulan data dan informasi terhadap mitra dilakukan dengan cara observasi dan wawancara terhadap kebutuhan dan situasi yang dialami mitra, proses bisnis, dan kendala yang dihadapi. Metode pelaksanaan pelatihan menggunakan metode PLA (Participatory Learning and Action). Pemaparan materi terhadap mitra dilakukan dengan pemberian informasi kegunaan imooji, pilihan paket yang disediakan, dan cara menggunakan imooji. Peserta pelatihan melakukan praktik secara langsung terkait penggunaan aplikasi. Praktik pelatihan yang dilakukan meliputi: 1) Cara masuk dan mendaftar sebagai pengguna baru; 2) Cara menggunakan user interface imooji; 3) Memilih template yang disukai dan cocok untuk produk Gusereen; 4) Melakukan unggah foto produk; 5) Mengganti teks ataupun gambar produk; 6) Melakukan penyimpanan dan preview imooji yang dibuat; dan 7) Melakukan publish atau berbagi imooji pada media seperti facebook, twitter ataupun whatsapp. Pelatihan ini berhasil meningkatkan pengetahuan peserta sebesar $45 \%$ dari nilai rata-rata 5,92 (pre-test) menjadi 8,58 (post-test). Peserta memperoleh manfaat dari pelatihan yang diberikan dan 87\% peserta memahami materi yang diberikan. Kegiatan pelatihan ini diharapkan menjadi awal dari transfer ilmu dan informasi kepada masyarakat pelaku usaha gula semut, terutama bagi pelaku usaha gula semut di Labuah Gunuang.
\end{abstract}

Kata kunci: imooji, pelatihan, pemasaran online, promosi

\begin{abstract}
Marketing of palm sugar products in District of Lima Puluh Kota is still managed traditionally, rarely use online marketing. Product marketing of Gusereen still relies on word of mouth and the limited use of groups on social media. This training activity aims to provide knowledge on how to make imooji digital brochures to increase promotion and sales of Gusereen products. The collection of data and information is conducted by observing and interviewing the needs and situations experienced by partners, business processes and obstacles faced. Training method is using the PLA (Participatory Learning and Action) method. Exposure of lesson materials to partners is conducted by providing information on the use of imooji, the choice of packages provided, and how to use imooji. Participants get lesson learn and guidance through the direct practices of using the application. The training practices carried out include 1) How to log in and register as a new user; 2) How to use the imooji user interface; 3) Choose a preferred and suitable template for Gusereen products; 4) Upload photos of the products; 5) Change text or product images; 6) Save and preview the created imooji; and 7) Publish or share imooji on social media. This training succeeded in increasing participants' knowledge by $45 \%$ from pretest to post-test. Participants benefit from the training provided and $87 \%$ of participants understand the material provided. This training is expected to be the beginning of the transfer of knowledge and information to the palm sugar business community, especially for palm sugar business actors in Labuah Gunuang.
\end{abstract}

Keywords: imooji, online marketing, promotion, training 


\section{PENDAHULUAN}

Usaha Mikro, Kecil, dan Menengah (UMKM) merupakan kegiatan usaha produktif milik perorangan atau badan usaha perorangan yang memberikan kontribusi dalam hal Produk Domestik Bruto (PDB) dan mampu meningkatkan penyerapan tenaga kerja (Prasetio et al. 2018). Salah satu kunci keberhasilan usaha adalah tersedianya pasar yang jelas, promosi, branding, minat berwirausaha, dan jaringan yang kuat baik dengan sesama pebisnis maupun pemerintah (Wijanarko \& Susila 2016), namun usaha perorangan ataupun UMKM masih banyak yang memiliki kelemahan mendasar dari sisi bidang pemasaran berupa orientasi pasar, lemah di dalam persaingan yang kompleks, dan tidak memiliki infrastruktur pemasaran yang memadai (Suci 2017). Penggunaan teknologi informasi dan ketersediaan informasi di dalam dan di luar usaha terkait aspek manajerial dan pemasaran sangat penting (Prasetio et al. 2018).

Pemasaran online dapat dijadikan sebagai salah satu peluang usaha dalam pengembangan pasar, terutama dalam hal melakukan promosi usaha. Electronic commerce (e-commerce) merupakan proses jual beli barang pada internet atau konsep pertukaran produk, jasa, dan informasi melalui jaringan informasi termasuk internet (Turban et al. 2018). E-commerce memberikan dampak positif bagi operasi bisnis dengan meningkatkan efisiensi, menghemat biaya, memperbaiki kontrol produk, memperbaiki rantai distribusi (supply chain), membantu perusahaan menjaga hubungan dengan pelanggan, dan pemasok (Yau 2002). Pelaku usaha saat ini harus mampu mengikuti perubahan ataupun pergeseran keinginan pasar di mana perusahaan yang tidak mengikuti perubahan akan tertinggal dan ditinggalkan oleh konsumen. Pemasaran online merupakan model pemasaran yang diperlukan dan kebutuhan pemasaran online ini akan semakin meningkat (Schwarzl \& Grabowska 2015).

Pemasaran berbasis online melalui website dan media massa memberikan peluang besar bagi pelaku usaha untuk mengembangkan pasar dalam menarik sasaran pasar yang dituju dan sebagai sarana promosi yang efektif terutama di masa pandemi covid-19 (Aditya \& Syahwani 2020). Pada kondisi pandemi covid-19 ini, masyarakat lebih banyak menghabiskan waktu dan beraktivitas di rumah, di samping faktor adanya himbauan dari pemerintah untuk melakukan pembatasan sosial berskala besar.
Imooji merupakan sarana online yang dapat digunakan sebagai sarana promosi efektif bagi usaha. Imooji dapat digunakan untuk membuat brosur, undangan suatu event dan katalog produk/jasa dengan gratis. Imooji mudah digunakan karena memiliki tampilan yang sederhana dan tidak memerlukan waktu yang lama dalam proses downloading template yang akan digunakan. Penggunaan imooji atau e-flyer mampu dan mempermudah penyebaran informasi hingga ke daerah yang jauh (Hidayat 2018). Layanan imooji dapat digunakan untuk membantu pemula bisnis dalam memasarkan produknya (Irawan et al. 2020).

Kegiatan pelatihan tentang strategi pemasaran berbasis online melalui imooji ini bertujuan untuk memberikan pengetahuan tentang cara pembuatan brosur digital untuk produk Gusereen. Gusereen merupakan produk dari mitra Noniludo Group yang berada di Jorong Talaweh, Nagari Labuah Gunuang, Kecamatan Lareh Sago Halaban, Kabupaten Lima Puluh Kota. Nagari Labuah Gunuang merupakan daerah penghasil gula aren di Kecamatan Lareh Sago Halaban. Kecamatan Lareh Sago Halaban adalah kecamatan dengan produksi gula enau terbesar di Kabupaten Lima Puluh Kota untuk tahun 2018 (BPS Kabupaten Lima Puluh Kota, 2019).

Produk gula semut banyak diproduksi dan dipasarkan oleh pengusaha kecil dengan menggunakan cara yang masih tradisional (Muhandri et al. 2020), belum memiliki brand maupun kemasan, namun produk Gusereen sendiri telah memiliki berbagai jenis kemasan (Gambar 1). Pemasaran produk Gusereen sendiri ditujukan bagi pelanggan pecinta kesehatan terutama penderita diabetes atau pelanggan yang melakukan diet sehat. Produk Gusereen sendiri memiliki permasalahan terkait pemasaran, di mana penyebaran informasi produk masih hanya mengandalkan words of mouth dan penggunaan grup di media sosial yang sangat terbatas dalam area pemasaran. Selama ini, Gusereen dipasarkan melalui pemasaran langsung, melalui pameran, dan menggunakan media sosial seperti facebook, instagram, dan penyebaran melalui whatsapp group. Kondisi pandemi saat ini menyebabkan Gusereen hanya mengandalkan pemasaran dengan menggunakan media sosial, sedangkan kegiatan mengikuti event ataupun pameran sudah tidak ada lagi.

Peluang pemasaran online yang tersedia tidak diikuti dengan keterampilan mitra dalam memanfaatkan teknologi internet untuk melakukan pemasaran produknya. Produk Gusereen harus 


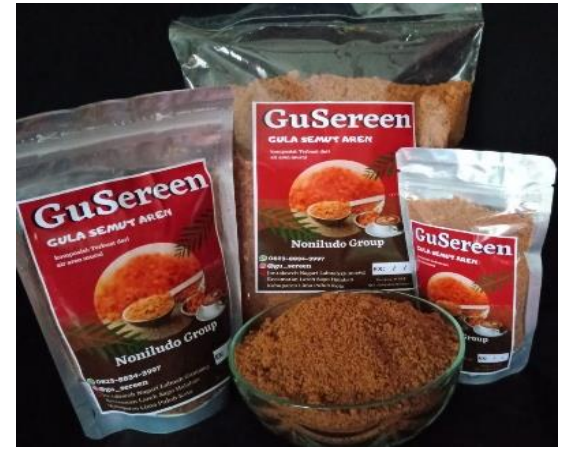

a

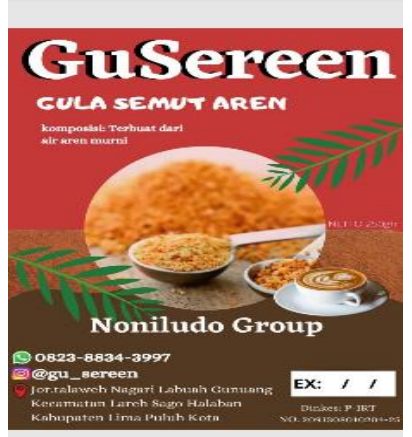

b

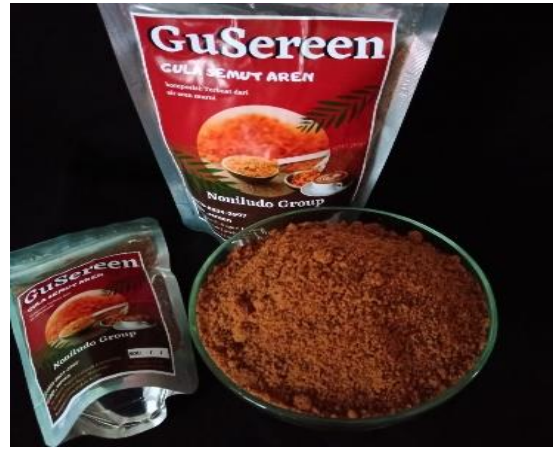

C

Gambar 1 a,b, dan c Produk Gusereen.

tergabung dalam pemasaran online untuk memasuki pasar yang kompetitif. Beberapa perangkat bauran pemasaran dan pengelolaan keuangan telah tersedia secara gratis dan daring. Mitra dalam memasarkan produk Gusereen-nya dapat menggunakan aplikasi untuk membuat brosur promosi secara elektronik, yaitu dengan menggunakan imooji. Aplikasi imooji menampilkan gambar produk disertai barcode yang dapat disebarkan melalui media sosial sehingga cocok jika diterapkan untuk produk Gusereen. Mengingat peran teknologi digital bagi UMKM maka penting untuk meningkatkan kesadaran dan pelaku usaha (Amalia \& Effendi 2020) terutama dalam menghadapi persaingan usaha di masa teknologi digital. Oleh karena itu, kegiatan pelatihan ini bertujuan untuk memberikan pelatihan dan pemahaman pemanfaatan aplikasi imooji sebagai media promosi dan penjualan produk bagi mitra.

\section{METODE PELAKSANAAN KEGIATAN}

\section{Waktu, Tempat, dan Partisipan Kegiatan}

Kegiatan pelatihan imooji dilakukan di Kampus Politeknik Pertanian Negeri Payakumbuh pada 21 November 2020 selama tujuh jam pelatihan (pukul 08.00-16.00 WIB). Pelatihan diberikan kepada mitra Noniludo Group sebagai salah satu pelaku usaha produk gula semut di Kecamatan Halaban, Kabupaten Lima Puluh Kota dengan brand Gusereen. Noniludo Group dipilih karena satu-satunya pelaku usaha yang telah memiliki label dan kemasan sendiri serta menerapkan pemasaran daring meskipun masih terbatas dalam penggunaan media sosial. Peserta pelatihan terdiri dari 8 orang yang melibatkan semua jajaran manajemen dari Noniludo Group (founder, owner, maupun pelaksana operasional usaha) dan pendamping teknis usaha dari Politeknik Pertanian Negeri Payakumbuh.

\section{Metode dan Tahapan Pelaksanaan Kegiatan}

Pengumpulan data dan informasi terhadap mitra Noniludo Group yang memiliki produk Gusereen dilakukan dengan cara observasi dan wawancara terhadap kebutuhan dan situasi yang dialami mitra, proses bisnis, dan kendala yang dihadapi. Alat dan bahan yang digunakan adalah komputer, website imooji, dan dokumentasi ataupun foto-foto produk. Kegiatan pelatihan ini diawali dengan tahap persiapan satu bulan sebelumnya dengan mempersiapkan pemateri dan persiapan peserta kegiatan pelatihan. Kegiatan pelatihan mengenai pembuatan brosur melalui imooji ini dilakukan untuk mendukung promosi produk, mengingat Noniludo Group dengan produk Gusereen-nya merupakan satusatunya pelaku usaha di daerah Labuah Gunuang yang memiliki label produk dan telah melakukan penjualan langsung sendiri secara daring maupun melalui pameran.

Metode pelaksanaan pelatihan menggunakan metode PLA (Participatory Learning and Action). Metode PLA ini merupakan proses learning by doing, terdiri dari proses belajar melalui ceramah, curah pendapat, dan diskusi yang dapat digunakan dalam metode pemberdayaan masyarakat (Ibnouf et al. 2015). Peserta pelatihan berperan aktif dalam diskusi dan praktik pembuatan imooji sebagai sarana promosi dan brosur online. Tahapan pelaksanaan kegiatan pelatihan adalah sebagai berikut: 1) Mempersiapkan peralatan pelatihan, fasilitator, dan tempat kegiatan; 2) Pemaparan materi terkait imooji; 3) Melakukan praktik langsung imooji untuk produk; dan 4) Melakukan pendampingan kelompok.

Sebelum kegiatan pelatihan dilakukan pre-test untuk mengukur tingkat pengetahuan peserta dan ditutup dengan post-test sebagai evaluasi kegiatan dan penyerapan materi bagi peserta pelatihan. Metode pre-test dan post-test banyak digunakan untuk membandingkan kelompok atau mengukur perubahan yang dihasilkan seca- 
ra desain eksperimental (Marsden \& Torgerson 2012). Pre-test dan post-test dilakukan dengan menggunakan formulir daring, yaitu google form yang berisi pertanyaan yang sama dalam bentuk pilihan ganda. Peserta pelatihan diberikan formulir pertanyaan yang berisi 15 pertanyaan terkait aspek teknis produk, aspek bauran pemasaran, platform media sosial, dan e-commerce ataupun pemasaran online.

\section{HASIL DAN PEMBAHASAN}

\section{Pelatihan Imooji}

Imooji merupakan salah satu sarana online yang dapat diakses melalui situs imooji.com. Imooji dapat digunakan untuk membuat brosur atau katalog digital interaktif, undangan event, order form untuk produk dan jasa menjadi lebih mudah. Imooji dapat dibagikan dengan orang lain. Beberapa cara untuk membagikan ulang imooji adalah dengan mengklik salah satu ikon (whatsapp, facebook, atau twitter) di halaman terakhir setiap imooji, melakukan copy URL imooji yang diterima dan disisipkan ke platform seperti whatsapp dan line sehingga dapat dilihat oleh target sasaran. Imooji yang dibagikan ini tidak hanya informasi judul saja tetapi juga dapat menampilkan sampul foto dan deskripsi singkat produk.

Penggunaan imooji tidak memerlukan pengunduhan aplikasi apapun untuk melihat dan berbagi imooji, meskipun disarankan lebih menggunakan browser Google Chrome untuk memperoleh pengalaman yang optimal. Imooji memiliki keunggulan berupa mudah dibuat, didesain untuk ponsel pintar, dan dapat melakukan panggilan aksi (call to action) di samping mudah dibagikan. Pelanggan dapat berinteraksi dengan hanya melakukan klik dan swipe konten imooji di gadget pelanggan. Imooji menyediakan berbagai macam template desain profesional dan dapat diganti dengan foto atau kata-kata sendiri. Selain itu, dengan adanya panggilan aksi (call to action) bagi pelanggan memudahkan pelanggan untuk langsung melakukan pemesanan sehingga mampu meningkatkan penjualan. Imooji menyediakan paket gratis, paket premium, dan paket pro. Paket gratis dapat mengakses basic tool (imooji v1.0) dan pro tool (imooji v2.0), jumlah halaman brosur maksimal sebanyak empat halaman, desain dibuat sendiri dan akan muncul ad banner milik pihak ketiga. Paket premium dapat mengakses pro tool (imooji v2.0), jumlah halaman brosur maksimal sebanyak delapan halaman, desain dibuat sendiri meskipun diberikan custom template and design dan tidak ada muncul ad banner milik pihak ketiga. Paket pro dapat mengakses pro tool (imooji v2.0), jumlah halaman brosur maksimal sebanyak delapan halaman, diberikan jasa pembuatan professional dengan ragam custom template and design yang disediakan dan tidak akan muncul ad banner milik pihak ketiga.

Kegiatan pelatihan imooji bagi pelaku usaha Gusereen (Noniludo Group) dilakukan dengan tahapan awal berupa pemaparan materi terkait imooji yang akan digunakan (Gambar 2). Pemaparan materi yang diberikan berupa informasi kegunaan imooji, pilihan paket yang disediakan oleh imooji, dan cara menggunakan imooji. Setelah peserta pelatihan diberikan tahapan detail terkait imooji maka dilakukan praktik secara langsung. Tahapan praktik pelatihan yang dilakukan meliputi: 1) Cara masuk dan mendaftar sebagai pengguna baru; 2) Cara menggunakan user interface imooji; 3) Memilih langsung template yang disukai dan akan cocok untuk produk Gusereen; 4) Melakukan unggah foto produk; 5) Mengganti text ataupun gambar produk; 6) Melakukan penyimpanan dan preview imooji yang dibuat; dan 7) Melakukan publish atau berbagi imooji di media yang dimiliki oleh Gusereen seperti facebook, twitter ataupun whatsapp (Gambar 3).

Peserta pelatihan diminta langsung memasukkan informasi produk Gusereen di dalam pembuatan imooji produk. Sebelum pelatihan dimulai, peserta telah diminta untuk mempersiapkan terlebih dahulu dokumentasi produk, seperti foto produk dengan berbagai variasi produk yang dimiliki dan testimoni pelanggan. Hal ini dilakukan dengan pertimbangan bahwa hasil imooji produk Gusereen dapat dijadikan langsung sebagai contoh promosi yang dapat dibagi di media sosial terkait (Gambar 4).

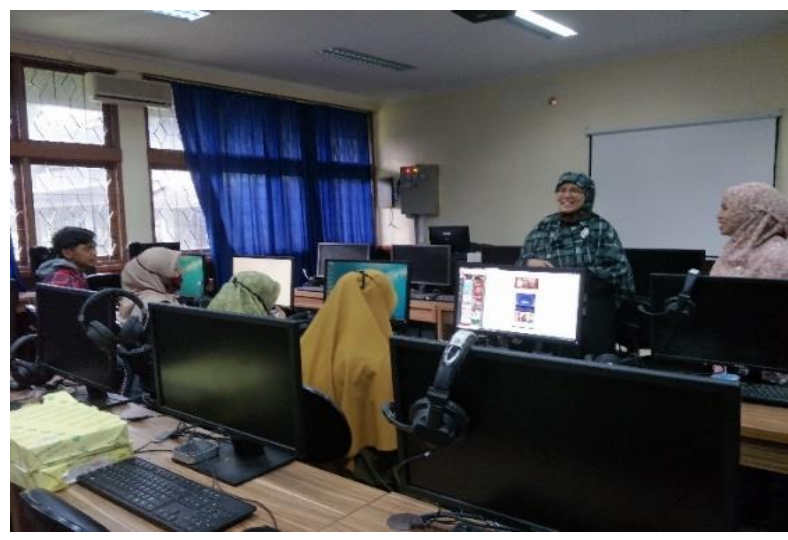

Gambar 2 Pemaparan materi pelatihan imooji. 


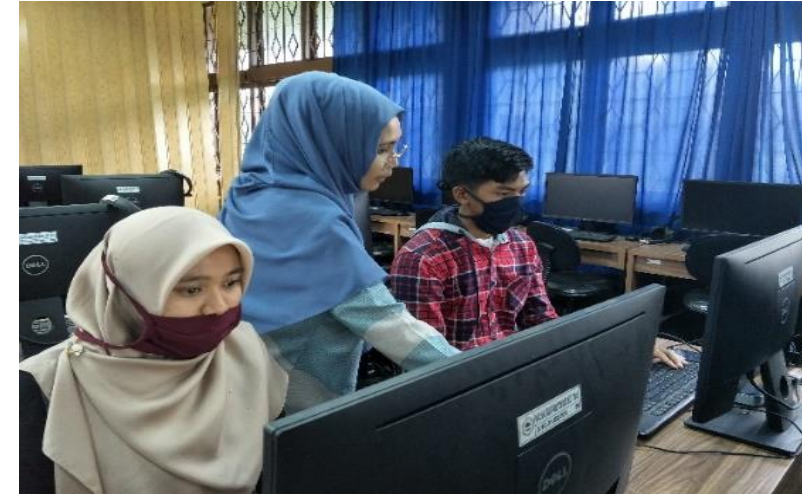

a

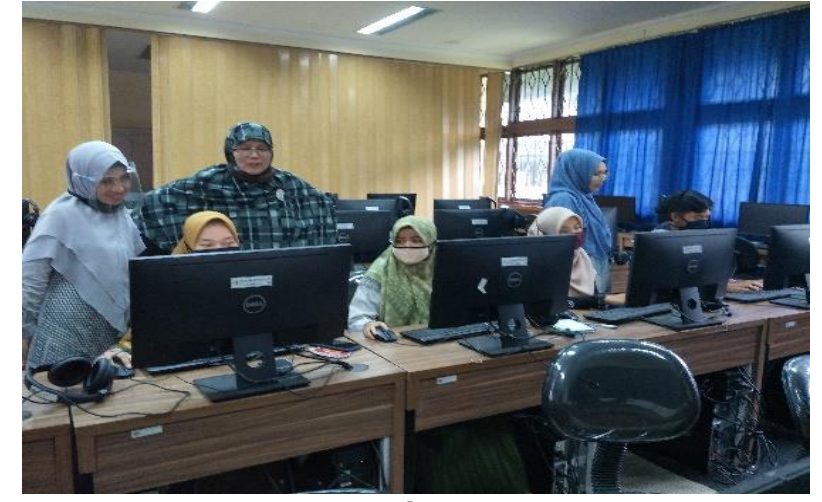

b

Gambar 3 a dan b Suasana pelatihan imooji.
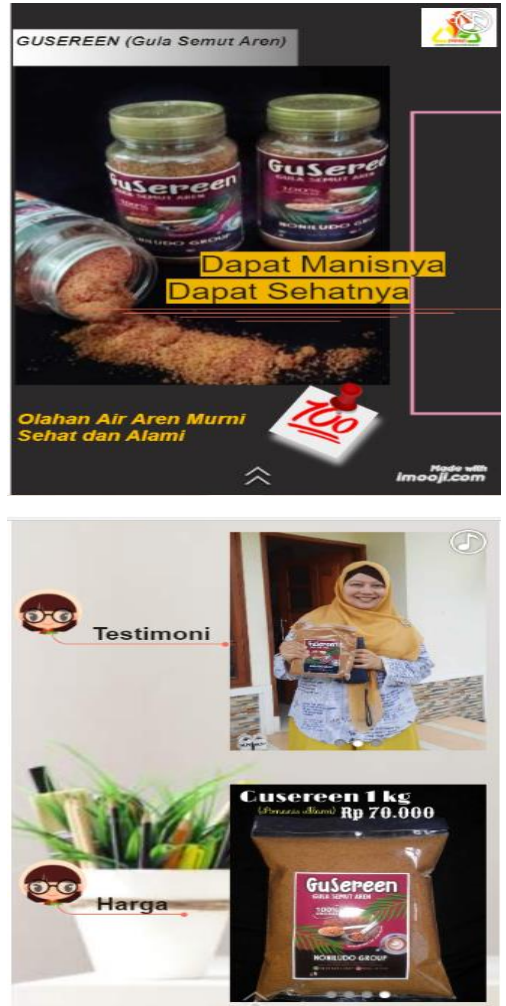
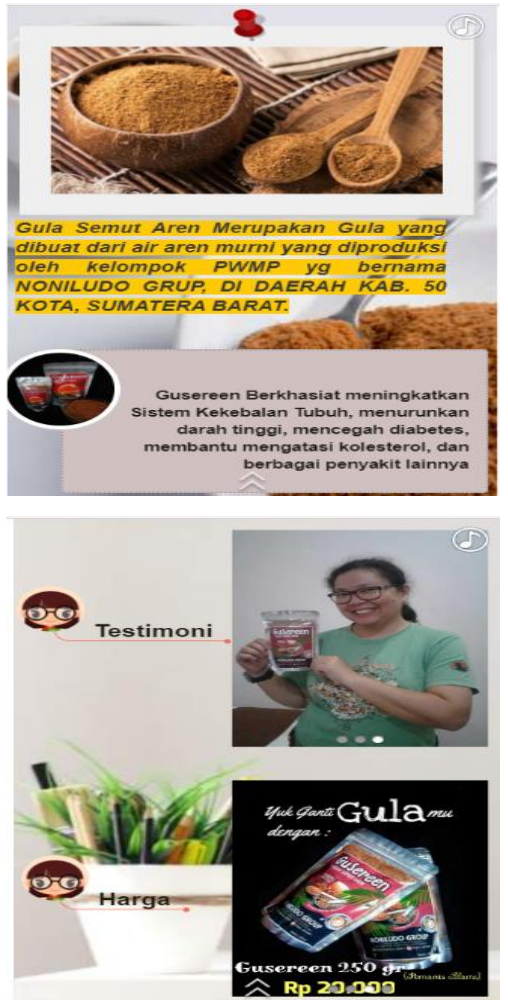

Gambar 4 Hasil imooji Gusereen.
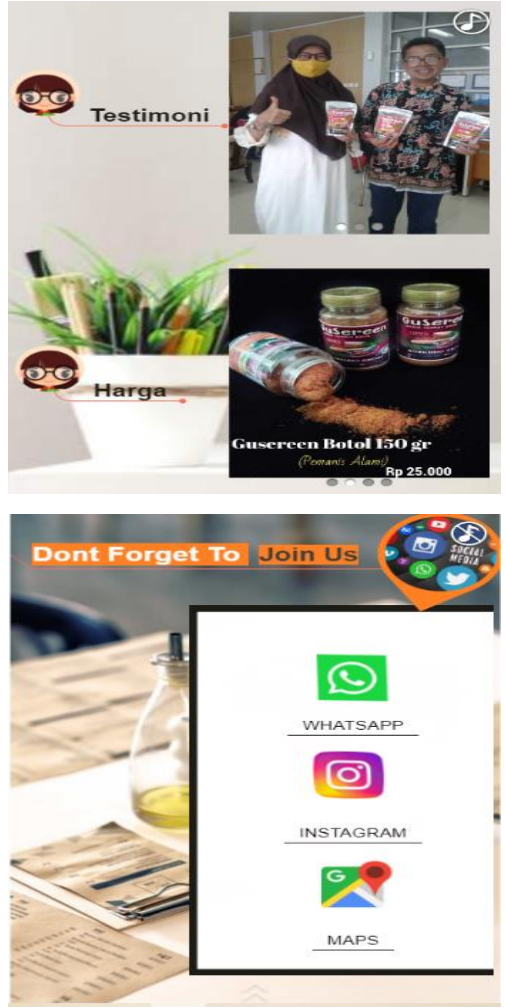

\section{Kendala Kegiatan}

Pelaksanaan pelatihan ini memiliki beberapa kendala dari persiapan pelatihan dan pelaksanaan pelatihan. Kendala yang dihadapi untuk melaksanakan kegiatan pelatihan ini adalah usaha menjaring pelaku usaha yang tertarik untuk memasarkan produknya secara langsung. Pelaku usaha masih terbiasa dengan sistem penjualan secara tradisional di pasar. Hal ini juga disebabkan oleh produk yang dihasilkan berupa gula aren, dan bukan gula semut sebagai produk lanjutan dari gula aren ini. Pelaku usaha baik pribadi maupun kelompok penghasil gula semut di Labuah Gunuang masih menyukai pemasaran produk secara curah secara langsung ataupun dengan menginformasikan produk di media sosial seperti facebook, dan penyebaran melalui whatsapp group. Pelaku usaha gula semut masih belum menyadari peluang usaha dengan melakukan pemasaran online dengan menyertakan informasi daring "tinggal klik di aplikasi".

Kendala yang dihadapi dalam pelaksanaan pelatihan adalah sense of design dari peserta pelatihan masih terbatas. Peserta pelatihan sudah mampu mengoperasikan imooji secara baik, namun masih belum mampu menampilkan desain yang menarik dan menjual. Hal ini terlihat dari tampilan imooji yang dihasilkan masih belum memiliki kombinasi ikon yang menarik, belum memuat informasi minimal terkait bauran pemasaran 4P (product, price, promotion, dan place), dan belum tersampaikannya dengan baik 
panggilan aksi (call to action) di dalam imooji yang dibuat.

\section{Manfaat dan Dampak Kegiatan}

Kegiatan pelatihan imooji bagi Noniludo Group dengan produk Gusereen diharapkan dapat membantu memberikan informasi kepada pelaku usaha terkait perkembangan dan alternatif pemasaran yang dapat dilakukan sebagai upaya berkelanjutan dari kegiatan pelatihan pemasaran online bagi pelaku usaha. Adanya katalog online imooji untuk produk Gusereen diharapkan dapat memberikan kenyamanan bagi pemilik Gusereen maupun pelanggan Gusereen. Hal ini terkait dengan promosi dari katalog imooji tersebut tidak memiliki batasan tempat dan waktu, memiliki jangkauan promosi yang lebih luas, efisiensi biaya promosi, memberikan pengalaman berbelanja yang lebih personal kepada pelanggan dengan membangun reputasi brand melalui pembelian dan preferensi pelanggan. Selain itu, pemilik Gusereen juga dapat membangun hubungan dengan pelanggan, dengan cara meminta testimoni pelanggan sehingga jika ada produk atau varian baru maka akan dapat diinformasikan kembali kepada pelanggan.

Indikator keberhasilan kegiatan pelatihan dari sisi proses terlihat dari hasil evaluasi yang didasarkan kepada tingkat pemahaman peserta terhadap materi dan respons peserta terhadap kebermanfaatan kegiatan pelatihan yang diikuti. Pemahaman peserta terhadap materi terbagi menjadi empat kategori, yaitu sangat paham, paham, kurang paham, dan tidak paham (Gambar 5a) sedangkan respons peserta terbagi menjadi sangat bermanfaat, bermanfaat, kurang bermanfaat, dan tidak bermanfaat (Gambar 5b). Materi pelatihan dirasakan peserta cukup mampu dipahami oleh peserta, yang terlihat dari respons peserta yang sangat paham terhadap materi (25\%), paham (62\%), kurang paham (13\%). Kegiatan pelatihan ini memberikan manfaat bagi peserta, yang terlihat dari respons peserta yang menganggap sangat bermanfaat sebesar $87 \%$, dan bermanfaat sebesar $13 \%$.

Karakteristik peserta pelatihan berdasarkan tingkat pendidikan menunjukkan bahwa peserta sudah memiliki dasar pendidikan yang cukup untuk memahami materi yang disampaikan dan merespons kegiatan. Pendidikan peserta pelatihan terdiri dari tamatan SMU sebesar 13\%, tamatan Diploma-III sebesar 50\%, dan telah memiliki gelar sarjana sebesar $37 \%$. Kemampuan memahami dan merespons kegiatan juga di- tunjukkan dari usia peserta pelatihan yang masih berada dalam rentang usia 20-40 tahun dengan mayoritas peserta berada pada usia \pm 24 tahun.

Kegiatan pelatihan ini juga memberikan pretest dan post-test untuk mengukur pemahaman peserta yang mengikuti pelatihan aplikasi sarana pemasaran online imooji. Pre-test dan post-test memiliki struktur pertanyaan yang sama sehingga pengetahuan peserta dapat dinilai untuk melihat perbedaan dan peningkatan yang terjadi saat sebelum dan sesudah diberikan pelatihan. Berdasarkan hasil tes yang dilakukan, terdapat peningkatan pengetahuan setelah diberikan pelatihan. Rata-rata jawaban yang tepat sebelum pelatihan adalah 5,92 dan rata-rata jawaban yang tepat setelah dilakukan pelatihan sebesar 8,58. Oleh karena itu, terjadi peningkatan pengetahuan peserta sebesar $45 \%$.

Pelatihan ini berhasil memberikan informasi pemanfaatan sarana aplikasi pemasaran online imooji kepada peserta pelatihan dan pembuatan katalog produk online secara langsung. Hasil berbagi (share) katalog online imooji Gusereen yang dilakukan telah dilihat lebih dari 100 orang semenjak satu minggu ditampilkan. Selain itu, kegiatan pelatihan kepada pemilik Gusereen diharapkan dapat menjadi awal dari transfer ilmu dan informasi kepada masyarakat pelaku

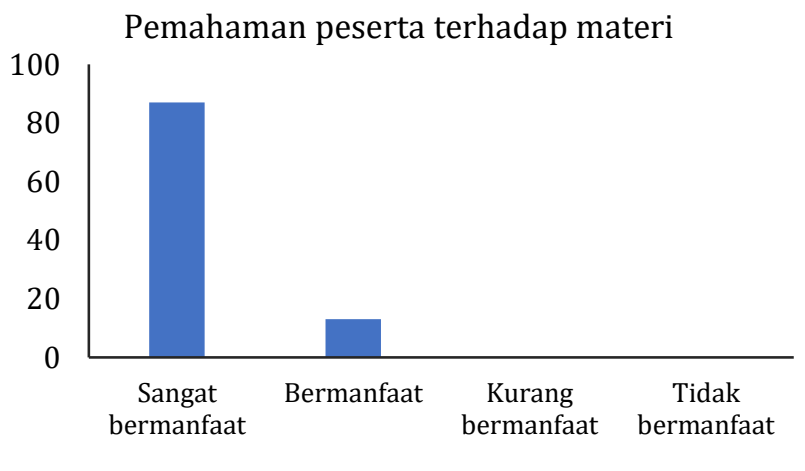

a

Respons peserta terhadap kebermanfaatan kegiatan pelatihan

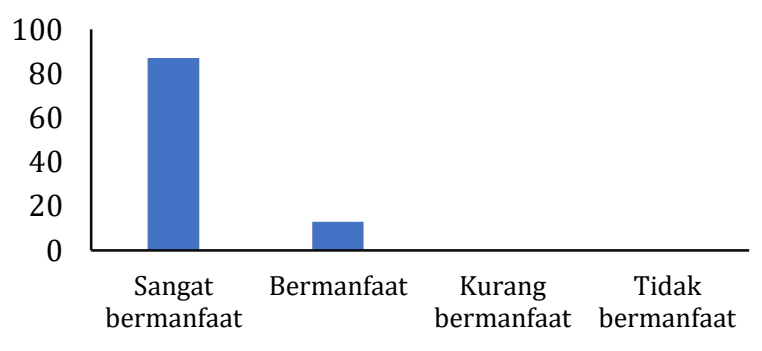

b

Gambar 5 a) Pemahaman peserta terhadap materi; dan b) Respons peserta terhadap kebermanfaatan kegiatan pelatihan. 
usaha gula semut. Hal ini mengingat peserta pelatihan merupakan pelaku usaha yang berasal dari anak muda sehingga transfer ilmu dan informasi menjadi lebih cepat, terutama bagi pelaku usaha gula semut di Labuah Gunuang yang lebih condong sebagai petani gula aren atau penjual produk curah saja.

\section{SIMPULAN}

Pemahaman dan keterampilan peserta pelatihan meningkat dengan adanya pelatihan sarana pemasaran online melalui imooji. Berdasarkan hasil tes (pre-test dan post-test) dan evaluasi pelaksanaan kegiatan menunjukkan peningkatan pengetahuan peserta (45\%), dan mayoritas peserta memahami materi yang telah diberikan serta memperoleh kebermanfaatan dari kegiatan pelatihan. Kegiatan pelatihan kepada pemilik Gusereen diharapkan dapat menjadi awal dari transfer ilmu dan informasi kepada masyarakat pelaku usaha gula semut, terutama bagi pelaku usaha gula semut di Labuah Gunuang. Ada beberapa kekurangan yang masih perlu mendapatkan perhatian terkait sense of design dari peserta pelatihan yang dapat diantisipasi dengan merekrut karyawan yang memiliki kreatifitas seni meskipun memiliki konsekuensi terkait anggaran biaya. Selain itu, kendala ini dapat diminimalisir dengan memperluas wawasan dan bergabung di komunitas desain ataupun komunitas wirausaha. Pelatihan lanjutan dan pendampingan terkait strategi jualan online dan promosi pada $e$ commerce diperlukan agar operasional bisnis menjadi efisien, bisnis tumbuh lebih cepat, dan meningkatkan penjualan.

\section{UCAPAN TERIMAKASIH}

Kegiatan ini dibiayai oleh Dana Program Penguatan Pendidikan Tinggi Vokasi (PPPTV) Tahun 2020, Direktorat Jenderal Pendidikan Vokasi, Kementerian Pendidikan dan Kebudayaan bagi Program Studi Agribisnis, Politeknik Pertanian Negeri Payakumbuh.

\section{DAFTAR PUSTAKA}

Aditya \& Syahwani A. 2020. Pelatihan Online Membuat Brosur Melalui Imooji untuk Mendukung Promosi UMKM Selama Pandemi
Covid-19 (Online Training of Making Brochures Through Imooji to Support The Promotion of The MSMEs During Pandemic. Jurnal Pusat Inovasi Masyarakat. 2(6): 957965.

Amalia M, Effendi I. 2020. Pelatihan Komunikasi Daring yang Efektif bagi Anggota Asosiasi Pengusaha Patin UKM Indonesia. Agrokreatif: Jurnal Ilmiah Pengabdian Kepada Masyarakat. 6(3): 260-268. https://doi.org/10.29244/ agrokreatif.6.3.260-268

[BPS] Badan Pusat Statistik Kabupaten Lima Puluh Kota. 2019. Kabupaten Lima Puluh Kota dalam Angka 2019.

Hidayat DP. 2018. Strategi Publisitas dalam Meningkatkan Brand Awareness RS Husada Utama Surabaya. [Skripsi]. Surabaya (ID): Sekolah Tinggi Ilmu Komunikasi Almamater Wartawan Surabaya.

Ibnouf MH, Sheqwarah MN, Sultan KI. 2015. An Evaluation of the Participatory Learning and Action (PLA) Training Workshop. Journal of Agricultural Science. 7(12): 144-150. https://doi. org/10.5539/jas.v7n12p144

Irawan PLT, Prilianti KR, Melany. 2020. Pemberdayaan Usaha Kecil Menengah (UKM) Melalui Implementasi E-Commerce di Kelurahan Tlogomas. Jurnal SOLMA. 9(1): 3344. https://doi.org/10.29405/solma.v9i1. 4347

Marsden E, Torgerson CJ. 2012. Single group, preand post-test research designs: Some methodological concerns. Oxford Review of Education. 38(5): 583-616. https://doi.org/ 10.1080/03054985.2012.731208

Muhandri T, Rifqi DM, Lestari T, Widodo S. 2020. Pelatihan Teknis dalam Rangka Perbaikan Mutu Gula Semut di Kabupaten Tasikamaya. Agrokreatif: Jurnal Ilmiah Pengabdian Kepada Masyarakat. 6(3): 276-280. https://doi.org/ 10.29244/agrokreatif.6.3.276-280

Prasetio RT, Mubarok A, Ramdhani Y, Junianto E, Rismayadi AA, Anshori IF, Hidayatulloh S, Topiq S. 2018. Upaya Peningkatan Produktivitas UMKM Melalui Implementasi ICT pada Look At Hijab Bandung. Jurnal Abdimas BSI. 1(1): 104-111.

Schwarzl S, Grabowska M. 2015. Online marketing strategies: the future is here. Journal of International Studies. 8(2): 187- 
196. $\quad$ https://doi.org/10.14254/20718330.2015/8-2/16

Suci YR. 2017. Perkembangan UMKM (Usaha Mikro Kecil Menengah) di Indonesia. Jurnal Ilmiah Cano Ekonomos. 6(1): 51-58.

Turban E, Outland J, King D, Jae-Kyu L, Ting-Peng L, Turban CD. 2018. Electronic Commerce 2018: A Managerial and Social Networks Perspective Ninth Edition. Switzerland $(\mathrm{CH})$ : Springer International Publishing. https://doi. org/10.1007/978-3-319-58715-8
Wijanarko A, Susila I. 2016. Faktor Kunci Keberhasilan UMKM Kreatif. Dalam: Prosiding Seminar Nasional Ekonomi Bisnis \& Call For Paper 2016. Universitas Muhammadiyah Sidoarjo. Sidoarjo (ID) 17 September 2016. Hal: 67-81.

Yau 0. 2002. An Empirical Investigation of the Impact of Business-to-business Electronic Commerce Adoption on the Business Operations of Hong Kong Manufacturers. First Monday. 7(9): 985. https://doi.org/ 10.5210/fm.v7i9.985 